\title{
DETECTION AND INVESTIGATION OF SOME PROPERTIES OF THE REGULATORS OF ANTIBIOTIC BIOSYNTHESIS PRODUCED BY STREPTOMYCES STRAINS $S$. SP. AN26 AND $S$. SP. B35
}

\author{
B.P. Matselyukh \\ Zabolotny Institute of Microbiology ans Virology, NAS of Ukraine, \\ 154 Acad. Zabolotny Str., Kyiv, 03143, Ukraine \\ e-mail: bohdan.matselyukh@gmail.com
}

\begin{abstract}
The aim of this work was the isolation, purification and some properties investigation of two regulators of antibiotic biosynthesis of streptomycetes. Methods includes extraction of regulators from agar cultures and their concentration by vacuum rotary evaporator, thin layer chromatography and spectrophotometry. Results. Two strains of streptomycetes AN26 and B35 isolated from soils of different regions of Ukraine produce the regulators restoring the landomycin E biosynthesis and sporulation in mutant strain Streptomyces globispoprus 1912-B2. Both regulators were purified by thin layer chromatography and have the same Rf 0.69. Absorption curves of regulators were established by means of spectrophotometry. Maxima of absorption of regulators were $232.5 \mathrm{~nm}$. The next study of the isolated regulators by means of NMR will give the possibility to elucidate their molecular structures. Conclusions. It is shown that two strains of streptomycetes isolated from the soils of Askania Nova and Brovary produce transcriptional regulators such as signaling molecules, which, like A-factor, restore the biosynthesis of antibiotics landomycin E and streptomycin in test strains S. globisporus 1912-B2 and S. griseis 1439, respectively. In terms of absorption maxima, they are similar and differ from similar indicators of known regulators of streptomycetes. It is possible that these compounds belong to new, not yet described signaling molecules, and the answer to this question will give future studies of their molecular structure by NMR spectroscopy.
\end{abstract}

Keywords: soil streptomycetes, S. globisporus 1912-B2, S. griseus 1439, transcriptional regulators.

Gram-positive bacteria streptomycetes are widely distributed in nature, namely, in soils, lakes, oceans and in associations with plants and invertebrates [1-3]. They are the important producers of the majority of antibiotics and other secondary metabolites with wide spectrum of the biological activities including regulators of antibiotic biosynthesis, immunosuppressors, pigments, enzymes and other compounds $[4,5]$.

Adaptation and response of streptomycetes to various environmental conditions are provided by regulatory systems. Antibiotic biosynthesis is controlled at different levels of structural organization and cell differentiation by a large number of genes products belonging to different families of regulatory proteins. We previously established that Streptomyces globisporus 1912 produced the new regulator of N-methylphenylalanyl-dehydrobutyrine diketopiperazine, which, like A-factor, restored the synthesis of antibiotics landomycin E and streptomycin by mutant strains of $S$. globisporus 1912-B2 and $S$. griseus 1439, respectively [6].

The aim of this work was isolation, purification and investigation of some properties of the new transcriptional regulators of antibiotic biosynthesis and sporulation of streptomycetes produced by strains $S$. sp. AN26 and $S . s p$. B35.

\section{Materials and methods}

Strains and media. Two mutant strains were used as the test system for screening of unknown regulators. The strain S. globisporus 1912-B2 is defective in biosynthesis of the signaling molecules gamma-butyrolactones and $N$-methylphenylalanyldehydrobutyrine diketopiperazine (MDD), an A-factor mimic that restores antibiotic biosynthesis and morphogenesis in this strain and $S$. griseus 1439 [6]. The last strain is defective in biosynthesis of A-factor, which belongs to the family of $\gamma$-butyrolactones, small signaling molecules that establish communication between the neighboring 
hyphae of streptomycetes [7, 8].

The corn-soy medium was used for isolation of streptomycetes producing the regulators $(\mathrm{g} / \mathrm{L})$ : corn meal - 20.0, soy meal-10.0, $\mathrm{NaCl}-5.0, \mathrm{pH}-7.2$, sterilization at 1.0 atmosphere during $30 \mathrm{~min}$. The investigating streptomycetes were put on the fresh lawn of the cultures 1912-B2 and 1439 in Petri dish in the form of spots with diameter of $1.0 \mathrm{~cm}$ and the results were examined after $3-5$ days of the cultures cultivation at $28^{\circ} \mathrm{C}$ as the appearance or absence of red zones of landomycin $\mathrm{E}$ or sporulation around the spots. The minimal solid medium was used for production and isolation of the regulators $(\mathrm{g} / \mathrm{L})$ : asparagine -1.0 ; glycine $-1.0 ; \mathrm{K}_{2} \mathrm{HPO}_{4}-0.5$; $\mathrm{MgSO}_{4}-0.2 ; \mathrm{NaCl}-4.0$; glycerol - 15.0; trace elements $\left(\mathrm{FeSO}_{4}, \mathrm{CuCl}_{2}, \mathrm{MnSO}_{4}, \mathrm{CaCl}_{2}, 10.0 \mathrm{mg}\right.$ each) in $1.0 \mathrm{~L}$ of distilled water, $\mathrm{pH} 7.2$, with sterilization at 0.75 bar overpressure for $30 \mathrm{~min}$.

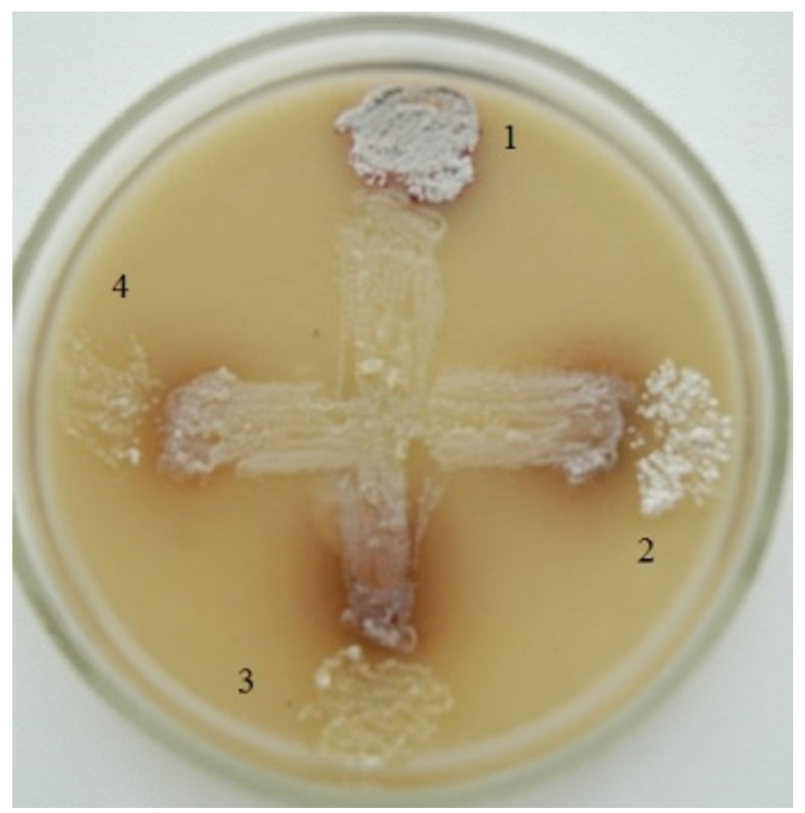

Fig. 1. Restoration of the biosynthesis of landomycin $\mathrm{E}$ (burgundy zones) by test culture of S. globisporus 1912-B2 (cross) under the influence of regulators of strains AN26 (2), B35 (3) and 14K (4), except for strain DL156 (1)

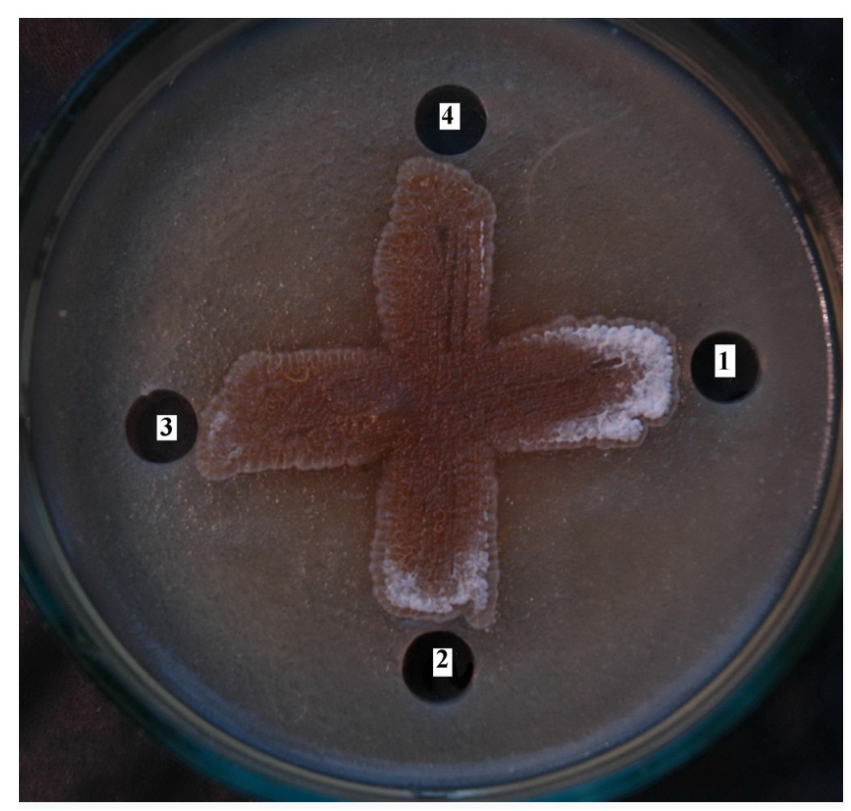

Fig. 2. Restoration of sporulation (white) by test culture of $S$. griseus 1439 under the influence of purified regulators of strains AN26 (well 1 lane 2 and well 2 lane 1 TLC) and B35 (wells 3 and 4 lane 2 and 4 TLC respectively) 
Purification and absorption spectra of the regulators. The minimal solid medium with the grown cultures of Streptomyces was cut into cubic pieces and extracted with chloroform-acetone (2:1) to obtain the unknown regulators.

The crude extracts were evaporated to dryness using a vacuum rotary evaporator and the residues were dissolved in ethanol. The chemical compounds were separated by thin layer chromatography using Silica gel 60 F254 aluminum sheets of Merck Co and system of solutions benzene-ethyl acetateacetone-ethanol (4:2:1:0.5). The individual stripes of the metabolites absorbing the UV light were removed from plates together with silica gel, dissolved in ethanol and the carrier was sedimented by centrifugation at $10000 \mathrm{rpm}$. The spectra of absorption of the regulators were obtained by means of spectrophotometer Beckman DU-8.

Results. The studied strains of streptomycetes AN26 and B35 were isolated from soil samples taken in Askania Nova and Brovary, respectively. Plating of these streptomycetes in the form of a spot to the ends of the bands of test cultures in the form of a cross in Petri dishes revealed the restoration of biosynthesis of antibiotics landomycin $\mathrm{E}$ and streptomycin in mutant strains S. globisporus 1912B2 and S. griseus 1439 (Fig. 1, 2).

Spores of cultures of strains AN26 and B35 were plated with lawn on soybean-corn medium in Petri dishes and after seven days of cultures growth, agar medium was cut into small cubes and filled with a mixture of chloroform and acetone (2:1) for extraction of regulators.

The extracts of regulators were evaporated in a vacuum rotary evaporator and the precipitate was dissolved in ethanol. The individual components of the obtained alcohol solutions of the metabolites were separated by TLC on Silica gel 60 F254 aluminium sheets in a solvent system of benzeneethyl acetate-acetone-ethanol (4:2:1:0.5). Fig. 3 presents an aluminum plate in UV light, which shows individual bands of metabolites of strains B35 and AN26. The silica gel of individual spots was scraped from the plates, dissolved in $300 \mu \mathrm{L}$ of $50 \%$ ethanol and the powder was precipitated by centrifugation at 5 thousand rpm for 5 minutes.

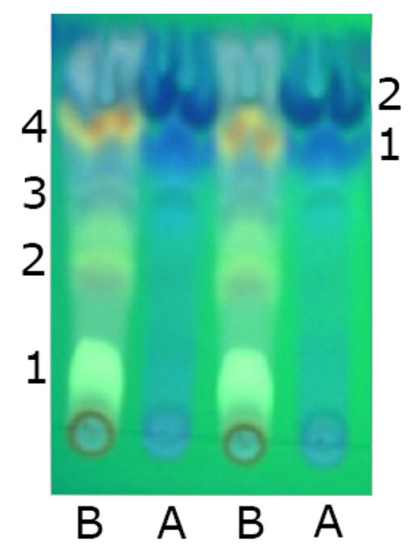

Fig. 3. Thin layer chromatogram of extracts of cultures of strains AN26 (A) and B35 (B) in UV light. The bands of individual metabolites are indicated by numbers.

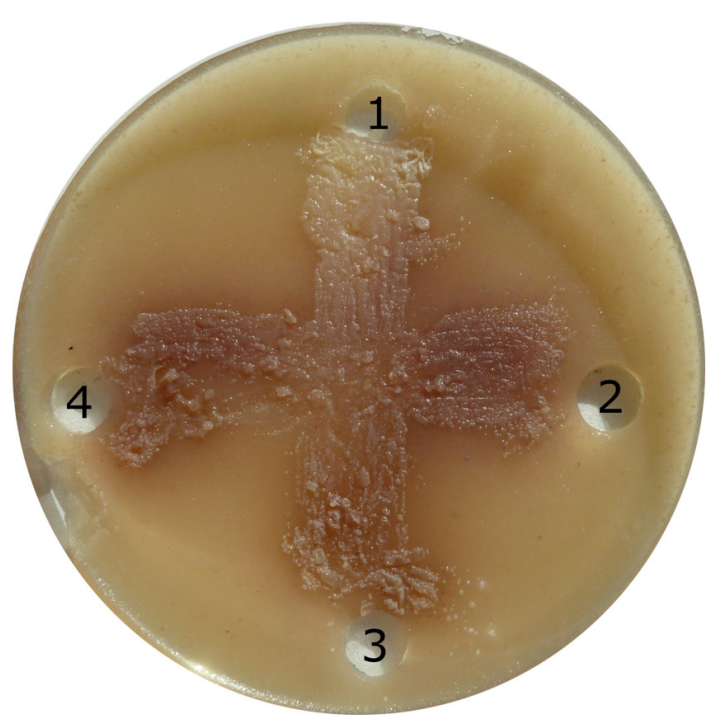

Fig. 4. Restoration of the biosynthesis of landomycin $\mathrm{E}$ (burgundy zones) by test culture of $S$. globisporus 1912-B2 (cross) under the influence of purified regulator strain AN26 (well 2 lane 1 and well 3 lane 2 TLC) and culture extract (well 4); well 1 front lane TLC of strain B35 
The obtained solutions of individual metabolites were added to $50 \mu \mathrm{L}$ in wells of agar medium near the strips of sown test cultures in order to identify regulators. Fig. 4 and 5 shows the restoration of the biosynthesis of the red antibiotic landomycin $\mathrm{E}$ by test culture 1912-B2 by regulators of strains AN26 and B35, isolated from individual TLC bands. The regulator of strain AN26 is found in lanes 1 and 2, and strain B35 - in lane 4. The Rf (relation factor) of both regulators is very similar and is 0.69 .

The next step was to study the absorption spectra of the regulators using a Beckman DU8 spectrophotometer. Fig. 6 shows the absorption curves of the regulators in UV light. As can be seen from the figure, both regulators are characterized

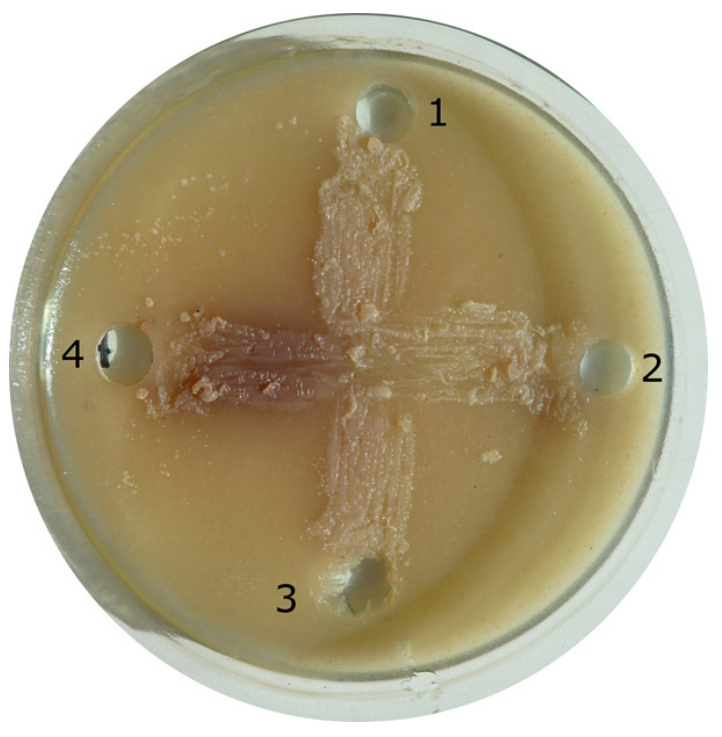

Fig. 5. Restoration of landomycin $E$ biosynthesis (burgundy zone, well 4) by test culture of S. globisporus 1912-B2 under the influence of purified regulator of strain B35 from band 4 TLC. In wells 1, 2 and 3, solutions of metabolites from bands 1, 2 and 3 of TLC B35 were introduced.

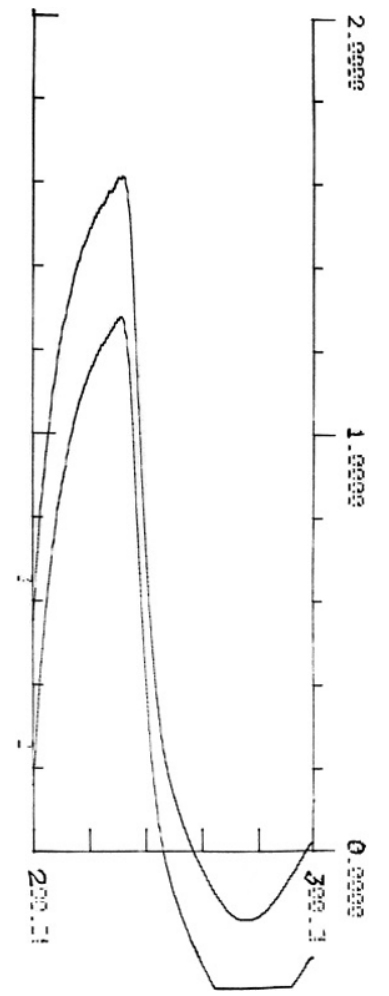

Fig. 6. Absorption spectra of regulators of strains AN26 (lower curve) and B35 (upper curve), purified by TLC (lane 1 AN26 and lane 4 B35) 
by similar absorption spectra with maxima at $232 \mathrm{~nm}$.

Discussion. The level of biosynthesis of antibiotics by streptomycetes depends on various environmental conditions and physiological processes that affect the concentration of hormonelike signaling molecules binding to cell receptors (proteins target) with next activation of global regulatory genes. Such ligands include A-factor and many other gamma-butyrolactones, furans, gammabutenolides, P1 factor and N-methylphenylalanyldehydrobutyrin diketopiperazine (MDD) $[9,10]$.

We have previously identified transcriptional regulators MDD, K4 and Tr144, which restored antibiotic biosynthesis and sporulation in mutant test strains $S$. globisporus $1912-\mathrm{B} 2$ and $S$. griseus 1439 like A-factor and were characterized by absorption maxima of 245, 255 and $255 \mathrm{~nm}$, respectively [10].

The AN26 and B35 regulators described in this work have absorption maxima of $232 \mathrm{~nm}$ and a retention factor (Rf) of 0.69 , which, on the one hand, may indicate their affinity and, on the other hand, their difference from the regulators listed above. To finally solve this problem, it is necessary to determine the molecular structure of these regulators using the nuclear magnetic resonance spectroscopy, which is planned to be done in the future.

Conclusions. It is shown that two strains of streptomycetes isolated from the soils of Askania Nova and Brovary produce transcriptional regulators such as signaling molecules, which, like A-factor, restore the biosynthesis of antibiotics landomycin $\mathrm{E}$ and streptomycin in test strains S. globisporus 1912-B2 and S. griseis 1439, respectively. In terms of absorption maxima, they are similar and differ from similar indicators of known regulators of streptomycetes. It is possible that these compounds belong to new, not yet described signaling molecules, and the answer to this question will give future studies of their molecular structure by NMR spectroscopy.

\section{ВИЯВЛЕННЯ І ДОСЛІДЖЕННЯ ДЕЯКИХ ВЛАСТИВОСТЕЙ РЕГУЛЯТОРІВ БІОСИНТЕЗУ АНТИБІОТИКІВ, ЩО ПРОДУКУ- ЮТЬСЯ ШТАМАМИ СТРЕПТОМІ- ЦE TIB $S$. SP. AH26 I S. SP. 635}

\section{Б.П. Мацелюх}

\author{
Інститут мікробіології і вірусології \\ ім. Д.К. Заболотного НАН Украӥни, \\ вул. Академіка Заболотного, 154, \\ Київ, 03143, Україна \\ $\mathrm{P}$ е 3 ю м е
}

Мета. Виділити, очистити і дослідити деякі властивості двох регуляторів біосинтезу антибіотиків стрептоміцетів. Методи. Екстракція регуляторів із агарових культур органічними розчинниками, їх концентрація за допомогою вакуумного роторного випарювання, тонкошарова хроматографія і спектрофотометрія. Результати. Два штами стрептоміцетів АН 26 і Б35, ізольовані з грунтів різних районів України, утворюють регулятори, які відновлюють біосинтез антибіотиків ландоміцину Е і стрептоміцину та споруляцію у мутантних штамів Streptomyces globisporus 1912-Б2 і S. griseus 1439 відповідно. Обидва регулятори, очищені за допомогою тонкошарової хроматографії, мають однаковий показник Rf 0,69. Максимуми абсорбції регуляторів були 232,5 нм. Наступне дослідження регуляторів за допомогою ЯМР-спектроскопії дасть можливість встановити їх молекулярну структуру. Висновки. Показано, що два штами стрептоміцетів, виділені з грунтів Асканії Нової і Броварів, продукують авторегулятори типу сигнальних молекул, які, подібно А-фактору, відновлюють біосинтез антибіотиків ландоміцину Е і стрептоміцину тест-штамів S. globisporus 1912-В2 і S. griseus 1439 відповідно. За максимумами поглинання вони подібні і відрізняються від аналогічнних показників відомих регуляторів стрептоміцетів. Цілком можливо, що ці сполуки відносяться до нових, ще не описаних сигнальних молекул, і відповідь на це питання дадуть майбутні дослідження їх молекулярної структури за допомогою ЯМР- спектроскопії.

Ключові слова: грунтові стрептоміцети, S. globisporus 1912-Б2, S. griseus 1439, транскрипційні регулятори. 
1. O'Brien J, Wright GD. An ecological perspective ofmicrobial secondary metabolism. Curr Opin Biotechnol. 2011; 22:552-558.

2. Seipke RF, Kaltenpoth M, Hutchings MI. Streptomyces as symbionts: an emerging and widespread theme? FEMS Microbiol Rev. 2012; 36:862-876.

3. Bakker MG, Schlatter DC, Otto-Hanson L, et al. Diffuse symbioses: roles of plant-plant, plant-microbe and microbemicrobe interactions in structuring the soil microbiome. Mol Ecol. 2014; 23:1571-1583.

4. Hopwood D. Streptomyces in nature and medicine: the antibiotic markers. Oxford University Press, New York, NY, 2007.

5. Odomnker S, Addo K. Bacteria resistance to antibiotics: recent trends and challenges. Int J Biol Med Res. 2011; 2(4):1204-2010.

6. Matselyukh B, Mohammadipanah F, Laatsch H, Rohr J, Efremenkova O, Khilya V. N-methylphenylalanyl-dehydrobutyrine diketopiperazine, an A-factor mimic that restores antibiotic biosyn- thesis and morphogenesis in Streptomyces globisporus 1912-B2 and Streptomyces griseus 1439. The Journal of Antibiotics. 2015; 68:9-14.

7. Anisova LN, et al. Regulators of the development in Streptomyces coelicolor A3(2). Izv Akad Nauk SSSR Biol. 1984; 98-107.

8. Pliner SA, et al. Isolation and primary characteristics of A-factor. Bioorg Chim. 1975; 1:70-76.

9. Guoqing Niu, Keith F. Chater, Yuqing Tian, Jihui Zhang, Huarong Tan. Specialised metabolites regulating antibiotic biosynthesis in Streptomyces spp. FEMS Microbiology Reviews. 2016; 40 (4):554-573.

10. Creamer KE, Kudo Y, Moore BS, Jensen PR. Phylogenetic analysis of the salinipostin $\gamma$-butyrolactone gene cluster uncovers new potential for bacterial signalling-molecule diversity. Microbial Genomics; 2021; 7: 000568.

11. Matselyukh BP, Lavrenchuk VY, Bambura OI. Screening and characteristic of regulators of antibiotic biosynthesis in Streptomyces. Mikrobiol Z. 2017; 79(2):95-102.

Received 8.07.2021 